Nataliia Sobol

ORCID iD 0000-0001-8082-9692

PhD (Pedagogy), Senior Lecture, Department of Instrumental and Performance Skills, Institute of Arts, Borys Grinchenko Kyiv University, 18/2 Bulvarno-Kudriavska Str., 04053 Kyiv, Ukraine, n.sobol@kubg.edu.ua

\title{
LIFELONG LEARNING: MUSIC ADULT EDUCATION
}

During the last decades in the modern society becomes more popular the idea of lifelong education which means the possibility of adults to join the educational environments for further professional development. In the current article we disclose the essence of the lifelong education in common and in the field of artistic education. In addition, we specify the adulthood age-peculiarities according to the educational expectations and define the role of educator (teacher, tutor) in the context of musical studies for adults. The contemporary educational system is characterized by the openness and availability. It is represented through the threefold structure which includes formal, non-formal and informal education. These types of lifelong education provide the opportunity to practice music for all who want to achieve their skills and get new knowledge. Among the adult audience the most popular forms of musical lifelong education are both formal and non-formal. Some adults begin to practice music for their work and some people choose music as a hobby. But all of these students have the same goals - to realize their self-development ambitions and improve themselves. According to these goals students could choose the place where to get the music education: at musical colleges, universities, academies, musical schools, studious or courses, at the private lessons with a teacher or with online coacher etc. In consequence of musical studies, the student can develop his/her music and performing competence. It provides formation of students' skills, knowledge and experience of musical activities. They learn how to do the everyday routines and prepare the interpretation of music pieces, how to organize and follow the self-guided work. In addition, during the musical classes students develop their aesthetic tastes and artistic tolerance, learning how to think about the artistic ideas in music pieces and how to build the interpretation plan according to composer's view. Following the basic frameworks of andragogy (the science about adults' education) the author highlights that music studies cannot be limited by the age of students. Contrary, the educational process obtains the new characteristics and qualities depend on who is a student - an adult or a child. But the author notices that teacher (tutor, educator) is a very important figure in the educational chain both with children and adults.

Key words: adults' education; lifelong education; musical andragogy; musical studies.

https://doi.org/10.28925/1609-8595.2019.1.1722

Introduction. Nowadays, the adults' interest in music is becoming more and more popular - both professionally and as a hobby. As a result a large number of private schools and studios have been opened. They offer individual and group singing classes, playing musical instruments, the study of theory and history of music, etc. In addition, there are manuals for self-tuition in music disciplines, and on the Internet you can find plenty of video lessons about how to learn to play or sing. Such pieces of advice come from both professional musicians and teachers, and from amateurs, whose learning methods and techniques may provoke a discussion.

Unfortunately, we did not find certain Ukrainian researches or methodological recommendations which cover the methodical provision of the process of musical adults training (playing on musical instruments (including piano) and vocals). Therefore we believe that a research on adult students' music education approaches on both theoretical and practical levels becomes relevant, inasmuch there are increases interest and demand for the study of musical disciplines among adults.
Objective of the article is to determine the specifics of the forms and content of music adult education in Ukraine. To achieve this goal, it is necessary to justify the essence of the following tasks: to reveal the content of the phenomenon of lifelong learning in general and andragogy as a science of adult education; to outline the specifics of adult education according to their age peculiarities; to define the essence and structure of adult music education; to outline the significance of a teacher in the process of adults music teaching music.

Modern forms of adult education. At the present moment the adult education system is characterized by its openness, that is, the ability to attract the widest possible audience to gain new knowledge throughout life regardless of the social status of a person and his/her prior professional experience. According to the researches about historical, philosophical and psychological preconditions for the formation of the lifelong learning concept, it has been established that its realization requires the desire to study throughout life for an individual, and the opportunity to study throughout life for society (Marufenko, 2013, p. 56).

Due to the expansion of modern society's educational 
needs and opportunities, there are distinguished three main areas of development of the adult education system, namely formal, non-formal and informal education. Adult education can be implemented in intramural and extramural (distance) forms, conducted in group and individual classes.

Formal education is defined as a traditional form of adult learning organization that meets the following requirements: the learning process is organized in special educational institutions and carried out by specially trained staff; after graduation a student must get a certificate of education of a state-recognized format; learning is systematized and characterized by the purposeful activity of a learner (Sysoeva, 2011, p. 33).

Formal education in Ukraine is provided by higher educational institutions of different levels of accreditation (state or private; full-time, part-time forms of study): universities, institutes, academies, colleges, technical schools, higher vocational educational institutions, masters programmes, postgraduate studies, doctoral studies, advanced training, obtaining a second specialty, a system of institutes of postgraduate education (Sigaeva, 2011, p. 38).

Non-formal education is an addition to formal education, which is carried out beyond its borders. An adult may obtain such education on courses, clubs, public associations and organizations, attending seminars, lectures, etc., which does not require getting a diploma (Martynets, 2015, p. 15). L. Sigaeva (2011) notes that a person does not need special conditions to begin studying in non-formal education (level of previous training, age limits, etc.), there are no strict requirements for place, time, terms, forms and methods of training, etc. (p. 39). It means that this type of education is realized and operated upon the condition of the will of all participants in the learning process and requires their great interest in a positive educational outcome.

Informal adult education can be conducted throughout life of a person under the influence of his/her everyday environment, professional atmosphere, family and friends, media, self-education, etc. (Martynets, 2015, p. 15). It never ends and does not provide documentary evidence (diplomas and certificates). Informal education creates the opportunity to adjust the educational process of each person according to his/her individual needs, to be autonomous and not to depend on external factors (Sigaeva, 2011, p. 39).

Andragogy as a science of adult education. Andragogy deals education of adults. Andragogy is a branch of pedagogy «which studies the processes of stimulation, education, retraining, self-improvement, self-development of an adult throughout his/her life» (Lukianova, 2014, p. 8-9). Andragogy scientists are interested in the study of forms and methods of organizing adult education in order to deepen knowledge, to ensure their educational and cultural needs, to achieve individual goals, and provide self-realization of an individual (Lukianova, 2014, p. 8-9). Ukrainian (O. Anishchenko, L. Lukianova, L. Martynets, N. Nychkalo, S. Sysoeva,
L. Sigaeva and others) and foreign (A. Moles, L. Turos, P. Furter, S. Zmeev, J. Kuliutkin, T. Sukhobska and others) scholars handle the problem of adult education.

One of the most famous English-speaking researchers and author of the main andragogy fundamental principles is an American researcher M. Knowles. He singled out the main features of andragogy as a science of adult education, in contrast to pedagogy, which is the science of children education. M. Smith (2002), generalizing M. Knowles's research, notes that adults who study acquire not only knowledge but also must always understand their motivation and know their learning opportunities; to be self-critical, but also respect his/her and successes and failures of others; to define the goals of studies and compare them with achievements. An important feature of adult education is dynamism in their own (internal) and social (external) changes that determine the desire to develop. Adults learn to interact with others, and therefore they must be able to identify and react to causes of action rather than their consequences. Moreover, adults receive an experience of self-development and the disclosure of their potential through education, how to realize themselves, develop and adapt their skills to the social demands.

According to the andragogy concept of M. Knowles, an adult studying is distinguished from a pupil by five basic features:

1) existence of a well-formed identity among adults, indicating their singleness;

2) existence of life experience, which in turn becomes a resource for learning;

3) adult's willingness for education, which determines his/her desire to enrich and develop him/herself as a performer of social roles;

4) orientation towards learning when an adult is able to change the orientation of his/her training from a generalized accumulation of knowledge to their application in practice, from simple studying to the realization of this knowledge in order to solve a problem situation;

5) adults have a well-formed inner motivation to study (Smith, 2002; Sysoeva, 2011, p. 30).

As we are interested in adult education, it is worthwhile to outline which cohort of people falls under definition «an adult student». According to T. Dzyuba (2013), an personality's adulthood is characterized by his/her maturity, which the researcher determines as the meaning of adolescence, the physiological state of an adult age person, social, psychological, personal, professional growth, which has a prominent acmeological orientation (p. 12).

There is no consensus on the determination of age gradation for adults. In psychology (Gordianko, 2012), since adolescence does not have a prominent dependence on the chronological age of a person and depends on the individual living conditions, behavior, values and experiences of each individual. But we will take an example of the gradation which is proved by T. Dzyuba (2013) based on the analyzed psychological concepts:

- Emerging adulthood (20-40 years) is characterized 
by the achievement of personal identity and the beginning of productive activity, which gives impetus to the construction of a system of new interpersonal relationships in professional and family spheres;

- Middle adulthood (40-60 years) - is the most important period in a life of adult when he/she has a possibility to unleash his/her potential in the most effective way and find a fulfillment in every sphere of his/ her life and fulfill his/her destiny; in this context, maturity becomes the goal of development, the achievement of prosperity, further development can be hidden beyond all of this;

- Late adulthood (60 years and more) - person's life and social activity changes completely, such person is inclined to rethink her past and future, she begins to seek out a new meaning of life or the sense of despair starts to develop and it needs some care from the side (p. 26-29).

Adult music education features in Ukraine. Many people are wondering: at what age should one start to study music, whether it is not too late to start at 20 , over 40,50 years old. It should be noted that there is no age limit for music studies. Because person acquires purely technical skills as well as aesthetic experience and creates artistic tastes, while practicing, which undoubtedly has a positive influence on his/her personal growth at any age. Also, one should not be afraid of weakly expressed musical abilities: musical hearing, the sensation of rhythm, vocal data, etc., because they are developed with a practice. However, there may be restrictions on choosing a type of musical activity if a person has medical contraindications, such as joints, respiratory diseases, etc.

I. Stashevska (2016) conducted an analysis of domestic and foreign studies and defined the term «musical education» as the result and the process of forming a musical culture and the overall development of the individual that has a permanent nature and implemented through musical training, education and development of the individual in the process of his dialectical interaction with the music world (p. 17). In the system of musical education as a social phenomenon and musical pedagogy as a science, the researcher also highlights musical andragogy, the content of which consists in studying the conditions, goals, diagnostics of the implementation of adult music education in institutions of education, private musical and pedagogical practice and self-education of adults (p. 19).

For the educational system of adults in the artistic sphere, the generally accepted gradation of its varieties: institutionalized (formal education) and noninstitutionalized (informal and informal education) forms (Oleksuk, 2016, p. 20). As we have already mentioned at the beginning of this paper, adult education in vocational education institutions (music colleges, universities, academies), music and art schools, studios, courses, clubs, private lessons with tutors, in self-study is gaining popularity in musical education online sources and more. The purpose of such classes may be the implementation of a student's child dreams, for example, learn to play piano or sing; recover lost skills after a long break or continuing musical education for professional growth; preparing for a speech at work or celebration in the circle of colleagues or relatives; finding a useful hobby lesson at your leisure time; self-development, human search and the realization of their talents. During the study of music, an adult-student must form a performing competency (Horbenko, 2015). Its acquisition is one of the key and most important indicator of successful learning in a class of musical instrument or vocals. In particular, the student receives knowledge, skills in musical activity and experience that directly affects the formation of his/her correct understanding of the routine and creative work of a musician, it teaches to work on a musical composition, to organize working space and to effectively use the time for classes, forms aesthetic the tastes and bases of artistic thinking, the construction of artistic interpretation, the performance of works to the public, contributes to the formation of artistic and creative tolerance, etc.

Very often an adult who comes to music classes tells the teacher what music pieces he/she would like to perform, and what exactly he/she expects from the classes. Most likely, it will either be a soundtrack from a movie, or a song by a famous artist, or a popular classical music piece. This should be taken into account during the work with an adult on music lessons - his/her interests, tastes and expectations. However, at this stage, a problematic situation may arise when the teacher is not familiar with contemporary popular music, or with contempt for modern works, which undoubtedly differ from classical pieces for artistic, technical and compositional characteristics. This conflict may be social in nature (the so-called «conflict of generations»), or be the result of the incompatibility of artistic preferences and aesthetic tastes, but the solution to this situation lies entirely in the area of teacher's pedagogical talent and professionalism.

In addition, it should be mentioned that conflict during the choosing of training repertoire can be improved if teacher and student display an artistic tolerance (Sobol, 2016). It is the ability of personality to find ways to understand and compromise with other people in aesthetic terms, that is, through artistic and creative activities.

Nowadays there is a large number of visual and remote resources that allow a person to independently choose and manage their learning. However, in the process of musical training for adult beginners, one should not diminish the value of the direct involvement of a teacher (tutor) in this process. Undoubtedly, the teacher plays a controlling role in working with children, because he/she selects the repertoire, works with the student technical work, motivates and controls the work in the class, directs the interpretation of musical works to the student, etc. Unlike children, an adult who comes to classes already has an experience of studying and self-study and is able to independently build the structure of his/her lessons. In spite of this, the individual work of «teacher-student» is an important element in teaching music for students of all ages and cannot be completely offset by materials for self-study or online lessons.

Firstly, musical performances often have a romantic coloring in the society, since there is the idea that music 
is not too serious, it is a hobby for enjoying leisure time. But after the first lessons the process of playing a musical instrument or vocals will necessarily challenge the student (technical and artistic), student cannot overcome them independently, no matter how talented he/she is. Thus, it is the teacher who will help diagnose the didactic problems of a particular student and provide methodological advice for their solution, using an individual approach.

Secondly, music lessons with adult-beginners need the individual pedagogical approach, since every adult student already has the own personal experience and approach for systematizing and assimilating information, established habits and peculiarities of his organization of work. Methodology, textbooks, courses and programs for learning playing the musical instruments or vocals focus on the average student. It is a kind of generalization of training tasks, challenges and risks, but they are not always able to take into account the individual needs of each student. Therefore, the task of a teacher as a tutor of educational activities of an adult grows precisely when studying artistic disciplines.

Thirdly, no matter how strong the motivation of an adult to study is, he/she always needs to be resumed. Encouragement is a prerequisite for student success. Adult person performs simultaneously many social roles, which build the structure of its vital priorities. The task of the teacher is to maintain the student's desire to study music at high positions and encourage him not to miss lessons, perform independent homework, conduct regular rehearsals, etc. For example, the presence of systematic controls and the implementation of sections of knowledge and educational achievements is a sufficiently strong incentive for the responsible student to work.

Thus, according to T. Vasilkova (2010), a teacher who works with adults should have psychological techniques and stimulate his student (p. 26-30):

- a sense of happiness and satisfaction with the learning process,

- transform the stress state, which is very common among adults due to a number of social factors that are destructive in a positive direction,

- encourage the student to take responsibility (attending classes, preparing for classes, taking responsibility for himself and a teacher or other student, etc.),

- motivation (internal or external) for cognitive activity due to the confidentiality of the learning process, the provision of positive feedback, support for student selfesteem and the use of purpose-setting techniques, etc.,

- avoiding conflicts concerning value, behavioral, organizational and other noncompliance options.

Conclusions. Adult music education plays an important role in the adult education system as a whole; in particular, scientists have identified even a separate branch for scientific research - musical andragogy. It is implemented in all three forms of adult education - formal, informal, non-formal, and involves 18-20 to 60 year-old students or more in Ukraine. Due to the learning objectives, the motivation and individual possibilities of adults engaging in music, the teacher must form a repertoire, organize classes and independent work of students, control and stimulate them to achieve educational goals, create a positive atmosphere for classes and support their students.

In future research, we plan to study the peculiarities of learning adult-piano games, outline the possible methodological and practical difficulties faced by teachers with such students, and identify ways to optimize the learning process for adults in the piano class.

\section{References}

Vasilkova, T. A. (2009). Osnovy andragogiki [The fundamentals of andragogy]. Moscow, Russia: KNORUS (rus).

Horbenko, O. B. (2015). Formuvannya vykonavskoyi kompetentnosti maybutnoho vchytelya muzychnoho mystetstva [Formation of music and performing competence of future music teacher]. ScienceRise. Pedagogical Education, 10 (5), 40-43. DOI: https://doi.org/10.15587/2313-8416.2015.51968 (ukr).

Hordiyenko, M. H. (2012). Psykholohichnyy aspekt vyznachennya doroslosti [Psychological aspects of definition of Adulthood]. Naukovi zapysky Nizhynskoho derzhavnoho universytetu im. Mykoly Hoholya, Psykholoho-pedahohichni nauky, 2, 11-14 (ukr).

Dzyuba, T. M., Kovalenko, O. H. (2013). Psykholohiya doroslosti z osnovamy herontopsykholohiyi [Psychology of Adulthood with fundamentals of gerontology]. Poltava, Ukraine: PNPU (ukr).

Lukyanova, L. B., Anishchenko, O. V. (2014). Osvita doroslykh: korotkyy terminolohichnyy slovnyk [Adult education: the short terminology dictionary]. Nizhyn, Ukraine: Lysenko M. M. (ukr).

Martynets, L. A. (2015). Osvita doroslykh: formy ta zmist [Adult education: forms and essence]. Osvita ta rozvytok obdarovanoyi osobystosti, 6, 14-17 (ukr).

Marufenko, O. V. (2013). Tendentsiyi rozvytku systemy neperervnoyi osvity v XXI stolitti [Tendencies of lifelong education in the XXI century]. Aktualni pytanny a mystetskoyi osvity ta vykhovannya, 1, 53-62 (ukr).

Oleksyuk, O. M. (2016). Neperervna mystetska osvita u formuvanni dukhovnoho potentsialu osobystosti [Continuing art education in shaping the spiritual potential of the individual]. Naukovi zapysky Kirovohradskoho derzhavnoho pedahohichnoho universytetu imeni Volodymyra Vynnychenka, Pedahohichni nauky, 147, 19-21 (ukr).

Sysoyeva, S. O. (2011). Interaktyoni tekhnolohiyi navchannya doroslykh [The Interactive adult-learning technologies]. Kyiv, Ukraine: EKMO (ukr). 
Sihayeva, L. Ye. (2011). Kharakterystyka struktury osvity doroslykh v suchasniy Ukrayini [The Characteristics of Adults' Education Structure in the Modern Ukraine]. Visnyk Zhytomyrskoho derzhavnoho universytetu imeni Ivana Franka, 59, 38-42 (ukr).

Sobol,N. V.(2016). Khudozhno-tvorcha tolerantnist u konteksti instrumentalno-vykonavs'koyi diyalnosti maybutnikh uchyteliv muzyky [Artistic tolerance within a context of future music teachers' instrumental performing training]. Muzychne mystetstvo v osvitolohichnomu dyskursi, 1, 29-34 (ukr).

Stashevska, I. O. (2016). Sutnist, struktura i vzayemozvyazky muzychnoyi pedahohiky yak naukovoyi systemy ta muzychno-osvitnoyi praktyky [Essence, structure and interrelations of musical pedagogics as scientific system and musical and educational practice]. Osvita ta pedahohichna nauka, 1, 13-23 (ukr).

Smith, M. K. (2002). Malcolm Knowles, informal adult education, self-direction and andragogy. The encyclopedia of informal education. Retrieved from www.infed.org/thinkers/et-knowl.htm (eng).

\title{
Література
}

Василькова Т. А. Основы андрагогики: учебное пособие. Москва: КНОРУС, 2010. 256 с.

Горбенко О. Б. Формування виконавської компетентності майбутнього вчителя музичногомистецтва. ScienceRise. Педагогічна освіта. 2015. Вип. 10 (5). С. 40-43. DOI: https://doi.org/10.15587/2313-8416.2015.51968.

Гордієнко М. Г. Психологічний аспект визначення дорослості. Наукові записки Ніжинського державного університету ім. Миколи Гоголя. Серія: Психолого-педагогічні науки. 2012. № 2. С. 11-14.

Дзюба Т. М., Коваленко О. Г. Психологія дорослості з основами геронтопсихології. Полтава: ПНПУ імені В. Г. Короленка, 2013. 172 с.

Лук'янова Л. Б., Аніщенко О. В. Освіта дорослих: короткий термінологічний словник. Ніжин: Видавець ПП Лисенко М. М., 2014. 108 с.

Мартинець Л. А. Освіта дорослих: форми та зміст. Освіта та розвиток обдарованої особистості. 2015. № 6. C. $14-17$.

Маруфенко О. В. Тенденції розвитку системи неперервної освіти в ХХІ столітті. Актуальні питання мистецької освіти та виховання. 2013. Вип. 1. С. 53-62.

Олексюк О. М. Неперервна мистецька освіта у формуванні духовного потенціалу особистості. Наукові записки Кіровоградського державного педагогічного університету імені Володимира Винниченка. Серія: Педагогічні науки. 2016. Вип. 147. С. 19-21.

Сисоєва С. О. Інтерактивні технології навчання дорослих. Київ: ЕКМО, 2011. 324 с.

Сігаєва Л. Є. Характеристика структури освіти дорослих в сучасній Україні. Вісник Житомирського державного університету імені Івана Франка. 2011. Вип. 59. С. 38-42.

Соболь Н. В. Художньо-творча толерантність у контексті інструментально-виконавської діяльності майбутніх учителів музики. Музичне мистечтво в освітологічному дискурсі. 2016. № 1. С. 29-34.

Сташевська I. О. Сутність, структура і взаємозв'язки музичної педагогіки як наукової системи та музичноосвітньої практики. Освіта та педагогічна наука. 2016. Вип. 1. С. 13-23.

Smith M. K. Malcolm Knowles, informal adult education, self-direction and andragogy. The encyclopedia of informal education. URL: www.infed.org/thinkers/et-knowl.htm (дата звернення: 29.01.2019).

\section{НАВЧАННЯ УПРОДОВЖ ЖИТТЯ: МУЗИЧНА ОСВІТА ДОРОСЛИХ}

\author{
Соболь Наталія, кандидат педагогічних наук, \\ старший викладач кафедри інструментально-виконавської майстерності Інституту мистецтв, \\ Київський університет імені Бориса Грінченка, \\ вул. Бульварно-Кудрявська, 18/2, 04053 Київ, Україна, \\ n.sobol@kubg.edu.ua
}

\begin{abstract}
Протягом останніх десятиліть у сучасному світі поширеною стає ідея навчання упродовж життя, що полягає у залученні дорослих в освітній процес з метою підвищення їх професійної кваліфікації. У статті ми розкриваємо зміст освіти дорослих загалом та у мистецькій сфері зокрема, окреслюємо специфіку навчання дорослих відповідно до їх вікових особливостей, визначаємо роль викладача у прочесі навчання музики дорослих. Сучасну освіту характеризує ї відкритість та доступність, що передбачають розподіл системи освіти дорослих на три основні напрямки, а саме формальну, неформальну та інформальну освіту. Вони забезпечують можливість усім бажаючим отримати музичну освіту в залежності від своїх цілей та потенціалів. Нині набуває популярності формальна та неформальна музична освіта - багато дорослих починають займатися музикою як професійно, так і аматорськи в якості хобі. Для одних ие стає реалізацією мрії дитинства, для інших - необхідністю для кар'єрного зростання. Однак всіх їх об'єднує бажання саморозвитку та самореалізаиії. Під час навчання музики у дорослого-учня має формуватися виконавська компетентність. Ї̈ набуття особистістю є однією з ключових
\end{abstract}


і найважливіших показників успішного навчання музики. Зокрема, студент отримує знання, уміння, навички у музичній діяльності та досвід, що безпосередньо впливає на формування у нього правильного уявлення про рутинну та творчу роботу музиканта, вчить самостійно працювати над музичним твором, організовувати робочий простір та ефективно використовувати час для занять, формує естетичні смаки та основи художнього мислення, побудови художньої інтерпретації, виконання творів на публіку, сприяє формуванню художньо-творчої толерантності тощо. У даному дослідженні ми підкреслюємо те, що згідно з основними положеннями андрагогіки як науки про освіту дорослих, навчання музиці не обмежується віком та навпаки набуває нових характеристик в залежності від того, хто навчається - дитина чи дорослий. Але єдиною незмінно важливою ланкою у процесі навчання музиці є безпосередній зв'язок студента з викладачем на занятті.

Ключові слова: музична андрагогіка; музична освіта; навчання дорослих; навчання упродовж життя.

\section{ОБУЧЕНИЕ В ТЕЧЕНИЕ ЖИЗНИ: МУЗЫКАЛЬНОЕ ОБРАЗОВАНИЕ ВЗРОСЛЫХ}

Соболь Наталия, кандидат педагогических наук,

старший преподаватель кафедры инструментально-исполнительского искусства Института искусств,

Киевский университет имени Бориса Гринченко,

ул. Бульварно-Кудрявская, 18/2, 04053 Киев, Украина, n.sobol@kubg.edu.ua

В течение последних десятилетий в современном мире распространенной становится идея обучения на протяжении жизни, которая заключается в привлечении взрослых в образовательный процесс с целью повышения их профессиональной квалификащии. В статье раскрывается содержание образования взросльх в целом и в художественной сфере в частности, определяем специфику обучения взрослых в соответствии с их возрастными особенностями, определяем роль преподавателя в процессе обучения музыке взросльх. Современное образование характеризуетего открытость и доступность, которые предусматривают распределение системы образования взрослых на три основных направления, а именно формальное, неформальное и информальное образование. Они обеспечивают возможность всем желающим получить музыкальное образование в зависимости от своих целей и потенциалов. Сейчас приобретает популярность формальное и неформальное музыкальное образование многие взрослые начинают заниматься музыкой как профессионально, так и любительски в качестве хобби. Для одних это становится реализацией детской мечты, для других - необходимостью для карьерного роста. Однако всех их объединяет желание саморазвития и самореализации. Во время обучения музыке у взрослогоученика должна формироваться исполнительская компетентность. Ее приобретение личностью является ключевым и важнейшим показателем успешного обучения музыки. В частности, студент получает знания, умения, навыки в музыкальной деятельности и опыт, который непосредственно влияет на формирование у него правильного представления о рутинной творческой работе музыканта, учит самостоятельно работать над музыкальным произведением, организовывать рабочее пространство и эффективно использовать время для занятий. В процессе приобретения исполнительской компетентности у студента формируются эстетические вкусы и основы художественного мышления, построения художественной интерпретации, исполнения произведений на публику, она способствует формированию художественно-творческой толерантности и тому подобное. В данном исследовании мы подчеркиваем, что согласно основным положениям андрагогики как науки об образовании взросльх, обучение музыке не ограничивается возрастом и наоборот приобретает новые масштабы в зависимости от того, кто учится - ребенок или взрослый. Но единственным неизменно важным звеном в процессе обучения музыке является непосредственная связь студента с преподавателем на занятии.

Ключевые слова: музыкальная андрагогика; музыкальное образование; обучение в течение жизни; обучение взросльх. 